Review article

\title{
The Potential of Silicon in Improving Rice Yield, Grain Quality, and Minimising Chalkiness: A Review
}

\author{
Engku Hasmah Engku Abdullah ${ }^{1}$, Azizah Misran ${ }^{1 *}$, Muhammad Nazmin Yaapar ${ }^{1}$, \\ Mohd Rafii Yusop ${ }^{1,2}$ and Asfaliza Ramli ${ }^{3}$ \\ ${ }^{1}$ Department of Crop Science, Faculty of Agriculture, Universiti Putra Malaysia, \\ 43400 UPM Serdang, Selangor, Malaysia \\ ${ }^{2}$ Laboratory of Climate-Smart Food Crop Production, Institute of Tropical Agriculture and Food Security, \\ Universiti Putra Malaysia, 43400 UPM Serdang, Selangor, Malaysia \\ ${ }^{3}$ Paddy and Rice Research Centre, Malaysian Agricultural Research and Development Institute, MARDI \\ Headquarters, 43400 Serdang, Selangor, Malaysia
}

\begin{abstract}
Silicon ( $\mathrm{Si}$ ) is a micronutrient that can increase the resistance of certain plants against multiple biotic or abiotic stresses. It is known that $\mathrm{Si}$ has a beneficial effect on plant growth, beginning in the soil, which could lead to a good crop yield. Despite its benefits, Si is not listed among the generally essential elements or nutrients for rice production in many countries such as Malaysia. This review discusses the ability to uptake $\mathrm{Si}$ and its benefits on rice. Environmental factors affect rice production, and among the factors, high temperature has been shown to disrupt the physiological development of rice grain, which contributes to chalkiness. Chalkiness is an undesirable trait that decreases grain's value, milling, cooking, and eating quality. The application of Si could ameliorate rice grain quality, thus providing a valuable reference for $\mathrm{Si}$ fertiliser use in high-quality rice production. This review also presents an update on the

ARTICLE INFO

Article history:

Received: 14 April 2021

Accepted: 22 July 2021

Published: 20 August 2021

DOI: https://doi.org/10.47836/pjtas.44.3.09

$\overline{\text { E-mail addresses: }}$

ehea77@gmail.com (Engku Hasmah Engku Abdullah)

azizahm@upm.edu.my (Azizah Misran)

muhdnazmin@upm.edu.my (Muhammad Nazmin Yaapar)

mrafii@upm.edu.my (Mohd Rafii Yusop)

aliza@mardi.gov.my (Asfaliza Ramli) potentials of $\mathrm{Si}$ in improving the rice yield and grain quality, including Si's ability to minimise grain chalkiness. Therefore, it is anticipated that Si applications will increase rice yield and grain quality and help to reduce chalkiness.

Keywords: Chalkiness, high temperature, rice quality, rice yield, silicon fertilisation
\end{abstract}

* Corresponding author 


\section{INTRODUCTION}

Rice (Oryza sativa L.) has fed more people in history than has any other crops. It serves as the primary source of dietary energy. It has a good proportion of proteins, vitamins, and minerals, thus providing the calorie requirements of the global population. Its indubitable importance has led to its extensive cultivation globally. In fact, it has become the second-highest cultivated cereal after wheat (Rajamoorthy et al., 2015). As a result, rice is a real food for over half of the world's population. The annual world rice production (based on milled rice) has increased from approximately 448 million metric tonnes in $2008 / 2009$ to more than 496 million metric tonnes in 2019/2020, as reported by the US Department of Agriculture (2021). By 2025, approximately 800 million metric tonnes of rice, a $25 \%$ increase, would be needed to meet the requirements of the human population.

In Malaysia, rice is an important crop. It is recognised as the third most widely planted after oil palm and rubber. Rice cultivation has always received particular attention in the effort to ensure the nation's food security. Rice demand is expected to continue with an increasing trend over the coming years due to the continuing urbanisation and increment of the global population. The Malaysian government has implemented various protection policies to ensure rice sustainability while attaining optimum self-sufficiency levels (SSL). The present rice SSL in Malaysia is around $72 \%$. Peninsular Malaysia has eight regions of granaries dedicated to ensuring rice SSL for the nation. Among these regions, northwest of Selangor is known as the most productive rice-growing area nationwide, hence being nicknamed 'The Rice Bowl of Selangor'. The area covers 36,602 ha with an average paddy yield of $4.8 \mathrm{t} / \mathrm{ha}$ and 174,088 tonnes of paddy production in 2019 (Ministry of Agriculture and Food Industries Malaysia [MAFI], 2019). Located in the west coast zone, northwest of Selangor experiences dry periods in February, June, and July.

Over $90 \%$ of rice is grown and consumed in Asia, which has the world's largest population. Rice cultivation mostly takes place in areas where the temperatures are already near-optimal for rice production. However, rice production is exceptionally vulnerable to environmental changes and severe conditions such as drought and flooding, which are issues in Malaysia. Consequently, any further increases in average temperatures or high temperatures above the optimal, particularly during reproductive and grain-filling periods, may reduce grain yields.

After milling, the physical appearance of grain is a significant determinant of consumer preference as rice is sold in milled form. These qualitative properties are readily attainable in many areas of the world. Although quality characteristics can be subjective and conflicting, the general population prefers rice with a uniform shape and translucent endosperm. Rice grain is thus termed chalky when it is not perfectly translucent in appearance. This trait, together with head yield, is the key characteristic used in determining the rice 
quality and its price. Chalkiness occurs mainly at the rice grain's central area, where at least half of the grain area is opaque white (Lisle et al., 2000). When this occurs, breakage during milling will ensue. As the proportion of chalky grains reaches $15 \%$, the quality of rice also decreases (Kim et al., 2000). Additionally, milled rice containing over $2 \%$ chalky grains is not accepted in certain regions (Lisle et al., 2000). Therefore, minimising chalkiness is a viable strategy for producing more head rice. Every $1 \%$ decrease in chalkiness is accompanied by a $1 \%$ increase in head rice yield (Zhao \& Fitzgerald, 2013).

Silicon (Si) is generally the most abundant element in the earth's crust. It can be absorbed by plant roots in large amounts, thus resulting in positive effects if applied to the soil where rice and many other crops are grown. Furthermore, $\mathrm{Si}$ is an element that improves resistance to multiple stresses, including biotic and abiotic stresses. Thus, it can stimulate plant growth while not causing harm, corrosion, and pollution, even in excess application. Several researchers had studied and demonstrated the improvement in physiological characteristics when Si was applied during planting (Liang et al., 2007). Although deemed a non-essential element for the growth of higher plants, Si seems to benefit certain plants, particularly in plants under stress conditions. Furthermore, many soils, including subtropical and tropical soils, are typically low in Si availability, so that supplemental Si will benefit both soil and cultivated crop. In the last 20 years, significant findings on the advantages of $\mathrm{Si}$ in several countries have helped develop Si fertilisation as an agronomic practice for several crops worldwide. Nonetheless, very little information on the application of $\mathrm{Si}$ in Malaysian agriculture is available. Therefore, this review aims to present an update on the potentials of Si on improving the rice yield and grain quality, including Si's ability to minimise grain chalkiness.

\section{Si Uptake and Deposition in Rice Plant}

After oxygen, $\mathrm{Si}$ is the second most abundant element, comprising approximately $29 \%$ of the solid earth's crust (Haynes, 2014). Si occurs not as a free element but bonded with other elements to form chemical compounds, such as silicon dioxide $\left(\mathrm{SiO}_{2}\right)$ (Heckman, 2012). Generally, Si is abundant in the soil as mineral quartz and clay, but its abundance in a soluble form (silicic acid; $\mathrm{H}_{4} \mathrm{O}_{4} \mathrm{Si}$ ) is highly variable. Silicic acid is absorbed by plants to be continuously transformed into insoluble polymers (Epstein, 1999; Ma \& Takahashi, 2002). Si can be added through irrigation water and fertilisation to improve the soil's physical, chemical, and biological properties. However, continuous cropping of land, natural weathering, or inherently deficient soils can be causes of $\mathrm{Si}$ deficiency. $\mathrm{Si}$, as a fertiliser, plays various essential roles in plants' mineral nutrition. It provides a nutrient beneficial for the robust and competitive growth of many crops, including rice (Ma \& Yamaji, 2006).

$\mathrm{Si}$ in the soil can be absorbed by plants largely by roots and directly affect plant development. However, the total elemental percentage of $\mathrm{Si}$ in the soil is not what 
the plant can utilise. Plant roots take $\mathrm{Si}$ as silicic acid (soluble molecule) mediated by transporters and translocated to leaves and shoots in the same form. The uptake of Si by the roots is facilitated by a type of transporter, namely Low silicon rice (Lsi). Lsi gene is responsible for controlling $\mathrm{Si}$ accumulation in rice. The absorption of $\mathrm{Si}$ in rice is mediated by transporters, Lsi1 and Lsi2 in roots and Lsi6 in shoots (Ma \& Yamaji, 2008). The uptake and transport of $\mathrm{Si}$ are illustrated in Figure 1.
Rice is a $\mathrm{Si}$ accumulator and requires a high amount of Si for stable, vigorous growth, and increased production (Ma \& Takahashi, 2002; Meena et al., 2014). Rice plants can take up Si in the range of 230 to $470 \mathrm{~kg} / \mathrm{ha}$ (Ma \& Yamaji, 2006). Over $90 \%$ of $\mathrm{Si}$ in the soil is taken up by roots and translocated to aerial plant parts (Ma \& Takahashi, 2002). Plants vary significantly in $\mathrm{Si}$ accumulation because of different abilities between different species to take

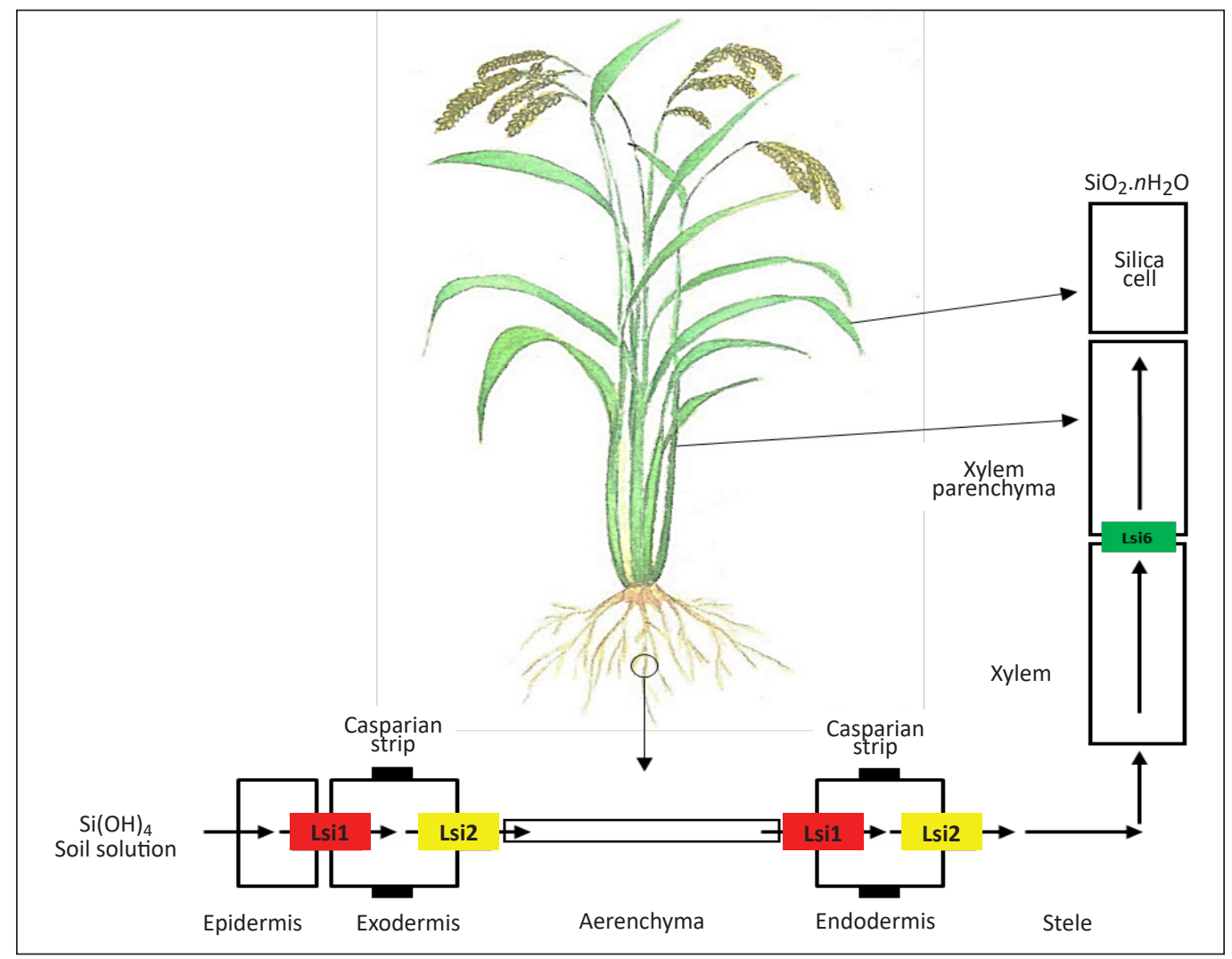

Figure 1. Si uptake system and transportation across the rice plant, mediated by Si transporter. Plant root takes up $\mathrm{Si}$ (as silicic acid) from soil solution through the root epidermis cell and transports it to exodermis cells by the passive Lsil and the active Lsi2. In the aerenchyma, Si moves apoplastically until it reaches the endodermis, where the Lsi1 and Lsi2 load Si into the stele. Si enters the xylem, mediated by an unknown transporter, travels further up into the leaves and shoots. Lsi6 is responsible for unloading the Si into the xylem parenchyma. $\mathrm{Si}$ is formed as amorphous silica $\left(\mathrm{SiO}_{2} . n \mathrm{H}_{2} \mathrm{O}\right)$ in the cell walls of shoots and leaves, called silica bodies or silica cells. Modified with reference (Ma et al., 2011; Ma \& Yamaji, 2015) 
up $\mathrm{Si}$ by the roots. Plant species with a $\mathrm{Si}$ content of more than $1.0 \%$ of dry weight are considered $\mathrm{Si}$ accumulators. In comparison, those with a range between $0.5 \%$ and $1.0 \%$ are considered intermediate species, and those with less than $0.5 \%$ are considered $\mathrm{Si}$ excluders. In higher plants, the highest $\mathrm{Si}$ accumulation in Gramineae is found in rice (Hodson et al., 2005) as Si is accumulated at up to $10 \%$ of shoot dry weight. This amount is higher than that of essential nitrogen $(\mathrm{N})$, phosphorus $(\mathrm{P})$, and potassium (K) macronutrients (Ma \& Yamaji, 2008). Therefore, Si has been used in increasing nutrient availability such as $\mathrm{N}, \mathrm{P}, \mathrm{K}$, calcium (Ca), magnesium $(\mathrm{Mg})$, sulphur $(\mathrm{S})$, zinc $(\mathrm{Zn})$, and decreasing mineral stress, such as nutrient toxicity of iron (Fe), aluminium (Al), manganese (Mn), cadmium (Cd), and arsenic (As) (Ma \& Yamaji, 2006).

A high level of Si uptake in rice is related to the superior ability of roots to absorb Si, much faster than that of water, and readily understandable by transpiration. Rice exhibited much higher Si uptake than other gramineous species like maize, sorghum, wheat, and barley (Ma \& Yamaji, 2006). More than $90 \%$ of total Si in the shoots exist as silica gel in the epidermal cell wall of leaves, stems, and hulls, forming a Si-cuticle double layer and a Si-cellulose double layer (Ma \& Takahashi, 2002). Si accumulation in cell walls improves their strength and rigidity, thus consequently increasing rice resistance to multiple threats, such as diseases, pests, and lodging ( $\mathrm{Ma}$, 2004; Ma \& Takahashi, 2002).

\section{Chalkiness Reduces Rice Quality and Acceptance}

Physically, chalky rice is more susceptible to breakage and reduces head rice recovery, consequently reducing millers' market value and economic returns. Along with head rice, chalkiness is used to determine the quality and price of rice in the markets. Chalky kernels have lesser starch granules density than translucent (unchalky) kernels, rendering them prone to breakage during milling (Ebron, 2013). In addition, chalky endosperm has a different cellular morphology in which starch granules do not develop adequately. The remaining air spaces between the granules reflect light, rendering the grains less translucent or chalky (Kim et al., 2000; Lisle et al., 2000; Zhaomiao et al., 2015).

Rice chalkiness formation is a complex physiological process closely associated with the biosynthesis and accumulation of starch in the endosperm. The physiological causes of chalkiness could be insufficient nutrient supply to develop endosperm, reduction of starch synthesis capabilities in the endosperm, and degradation of starch during ripening (Yamakawa et al., 2007). Great attention has been focused on the study of starch and amylose. Amylose content is the foremost criterion of grain quality used to indicate rice starch quality. Chalky rice tends to be low in amylose but high in amylopectin compared to translucent rice (Lisle et al., 2000; Patindol \& Wang, 2003). The quality differences between chalky and translucent rice in texture as well as cooking and eating quality of cooked rice have been 
studied (Chun et al., 2009). Chalky rice is softer than translucent rice and can easily absorb water during cooking. Due to the loosely packed starch granules, its volume expansion ratio is slightly higher than that of translucent rice. The low amylose content of chalky rice results in a more soluble solid, thus leading to its lower eating quality. The lower gelatinisation indicates a more shortbranched amylopectin structure in chalky grain. The sensory analyses on cooked chalky rice revealed lower quality and acceptance (Chun et al., 2009).

All the physical appearance, milling properties, nutritional value, and cooking quality are related to the content and composition of starch and protein in the endosperm. Like starch, protein is another main component of rice endosperm. Therefore, it is also the key to determining the rice's nutritional value. Furthermore, the protein content can affect the cooking quality as protein-starch interaction can impede the starch gelatinisation and disruption of the structure of the protein during cooking increases the viscosity of cooked rice (Yu et al., 2008).

\section{Temperature Affect the Rice Yield and Quality}

Rice is a tropical cereal, but it is also grown in some temperate zone where the average annual temperature is not extreme. The quality of rice grains during the growing season is affected by genetic and environmental conditions. Global warming and climate change threaten not only the rice yield but also its quality.
The frequency and intensity of drought, together with rising temperatures, pose a severe challenge to rice production. High temperatures, especially during grain filling, can cause significant damage to rice grain quality. Continuous cloudy weather or rainfall, particularly during grain-filling, often results in significant yield losses and poor grain quality. The grain-filling stage is considered vulnerable when exposed to extreme conditions, especially high and low temperatures. The other environmental elements include solar radiation, atmospheric carbon dioxide, light, water, and soil nutrient (Patindol et al., 2015).

Due to global warming, rice production and grain quality characteristics have been influenced, for example, when temperature increases over a certain threshold level for a particular duration which is sufficient to cause unalterable damage to plant growth. For each degree Celsius increase in global mean temperature, there is a decrease in rice yield. Research by Gumel et al. (2017) on the impact of climate change in Malaysia, particularly in granary areas of Muda Agriculture Development Authority (MADA), Kemubu Agriculture Development Authority (KADA), and Integrated Agricultural Development Area (IADA) showed that an increase of temperature above the optimal level for rice production has contributed to yield reduction. They revealed that an increase of $1{ }^{\circ} \mathrm{C}$ in the maximum temperature caused a decrease in yield from $0.2 \%$ to $4.5 \%$ for MADA and KADA during the mian season 
and $0.5 \%$ to $2.3 \%$ for MADA and IADA during the off-season.

Al-Amin et al. (2010), in their study on climate scenario in Malaysia, predicted that yields of rice would fall between $4.6 \%$ and $6.1 \%$ due to a rise of $1{ }^{\circ} \mathrm{C}$ in temperature at the current level of $\mathrm{CO}_{2}$ concentration, with the probability of a further decrease in yield with increasing temperature. With this scenario, they projected that by 2060 , rice productivity would be reduced by $34.8 \%$ per hectare. This prediction was supported by Vaghefi et al. (2013), who studied the effects of climate changes on rice yield for both main and off-seasons during 2013 until 2030 in eight main granaries in Peninsular Malaysia. Based on predicted weather and crop management practices, an expected increase of temperature and rainfall throughout the growing period would reduce the rice yield by $18.6 \%$ for the main season and up to $45.5 \%$ for the off-season. These findings showed that rice yield would be more negatively affected by climate change during the off-season than the main season, which could be explained by differences in minimum and maximum temperatures and rainfall between the main and off-season. The maximum and minimum temperature and rainfall were projected to increase about $0.05^{\circ} \mathrm{C}$ and 0.12 $\mathrm{mm}$ per year, respectively, during the main season. However, during the off-season, the minimum and maximum temperatures were projected to increase about $0.19^{\circ} \mathrm{C}$ and $0.08^{\circ} \mathrm{C}$ per year, respectively. At the same time, rainfall would decrease by about 0.18 mm per year.
Global warming impact yield and facilitate the chalky formation and affects the milling quality of rice (Ishimaru et al., 2009; Radziah et al., 2010). Hightemperature stress during grain filling boosts the formation of chalky grains, resulting in irregular-shaped amyloplasts, which consequently lead to breakage during milling (Wei et al., 2010; Yamakawa et al., 2007). According to Cooper et al. (2008), rice grain quality is significantly reduced by the high temperature of $35^{\circ} \mathrm{C}$ if exposed longer than five days during grain filling. They observed that rice grain quality is good at the optimum temperature of $22^{\circ} \mathrm{C}$ to $25^{\circ} \mathrm{C}$ during grain filling. With a rise in nighttime temperatures, the chalky kernels increased. However, in field conditions of four dry and wet seasons, Zhao and Fitzgerald (2013) reported that high temperature as a single parameter does not lead to chalkiness. They suggested that other than high temperature, climatic parameters like relative humidity (RH) and vapour pressure deficit (VPD) in combination might also be contributing. Low RH and high VPD in the dry season resulted in low chalky rice and high head rice even with the maximum temperature. However, in the wet season with the opposite condition, the chalky grain was high with a lower head rice yield.

The formation of kernel chalkiness is associated with the kernel development within the endosperm, which includes the synthesis of starch and the structure and arrangement of starch granules (Yamakawa et al., 2007). According to Kaneko et al. (2016), high temperature has 
increased soluble starch content in chalky grains. However, those in translucent grains were not changed, regardless of environmental stress. These indicate that starch degradation, instead of starch synthesis, is involved in chalky grain formation at the grain-filling stage and is influenced by the high-temperature stress. High temperature can also decrease the level of metabolic compounds associated with starch biosynthesis; hence starch production in the endosperm declines (Cao et al., 2009). Additionally, the amylose content tends to decrease, increase, or remain depending on different varieties. Grains at high temperatures have lower compactness of amylose (starch granules) (Cheng et al., 2005) as compared to low temperatures (Cooper et al., 2008).

Under optimum conditions, the edible part of rice grains, the endosperm, comprises starch granules yielding hard vitreous translucent grains. However, starch synthesis is weakened in ascertain conditions and results in less starch per endosperm or smaller starch granules. Some enzymes involved in starch biosynthesis are susceptible to a temperature above optimal conditions, affecting starch deposition (Fitzgerald \& Resurreccion, 2009). For example, heat stress during grain filling can increase chalkiness due to increased activity of $\alpha$-amylase, the hydrolysing starch enzyme. The enzymatic activity and gene expression of $\alpha$-amylase increased more than twofold in response to increased temperature during the ripening period. In contrast, the expression of many genes involved in starch biosynthesis was regulated, preventing starch accumulation (Yamakawa \& Hakata, 2010).

\section{The Potential of Si in Improving Rice Yield and Chalkiness}

Research on Si started in Japan at the beginning of the twentieth century when $\mathrm{Si}$ content was lower in rice leaves infected with blast disease. The relationship between Si and rice blast disease was studied extensively several years later until they realised that silicate application could increase the rice resistance to blast disease. Numerous studies were conducted to discover the physiological role of Si. In the 1930s, Si became significantly crucial for the growth and stability of rice production (Ma \& Takahashi, 2002). However, Si was not applied in the rice field since Si was naturally abundant in the soil. Therefore, they assumed that the application of $\mathrm{Si}$ to the soil was unnecessary. Moreover, at that time, specific Si fertilisers were also not available. The application of $\mathrm{Si}$ on rice fields started after the Second World War when a special project was implemented to improve degraded paddy soils due to a food shortage (Ma \& Takahashi, 2002). Si source, a by-product from the iron industry (calcium silicate slag), was used. Results showed that Si application helped to enhance productivity in declined paddy soils.

Many field trials have shown that $\mathrm{Si}$ as silicate fertiliser, either as organic or inorganic silicate, could significantly increase rice yield. Therefore, organic silicate materials such as rice straw and 
silicate slag are widely used in many countries as alternative materials for inorganic silicate fertilisers (Ning et al., 2016). In addition, rice husks obtained from the rice-milling industry have been used as a source of $\mathrm{Si}$ in some countries like Japan. Nevertheless, this is not a standard practice due to the complex decomposition in the soil.

Si fertiliser has been reported to have a beneficial role in enhancing rice yield (Agostinho et al., 2017; Cuong et al., 2017; de Oliveira et al., 2019; Emam et al., 2014; Guntzer et al., 2012; Li et al., 2020; Liang et al., 2015; Siregar et al., 2021). In terms of yield components, Si improved the number of spikelets per panicle, spikelet fertility, and grain weight of rice (Ma et al., 1989; Takahashi, 1995). Furthermore, in the early 1960s, Okuda and Takahashi (1961) revealed that Si application had improved the plant height, grain weight, and Si uptake when Si was applied at later growth stages (after panicle initiation stage) compared to earlier growth stages. These indicated that Si application is more crucial at later growth stages rather than earlier stages. Furthermore, the addition of Si at the reproductive growth stage increased the number of spikelets, the percentage of ripening, and the grain weight (Nhan et al., 2012).

It is estimated that a rice crop that produces a total grain yield of $5 \mathrm{tan} / \mathrm{ha}$ can remove Si from the soil at a rate of $230 \mathrm{~kg} /$ ha to $470 \mathrm{~kg} / \mathrm{ha}$ (Savant et al., 1997). Thus, Si may become a yield-limiting factor for rice production, necessitating exogenous $\mathrm{Si}$ fertiliser for an economical and sustainable rice production system. Calcium silicate slag is commonly applied by growers at $900 \mathrm{~kg} / \mathrm{ha}$ of Si up to $1500 \mathrm{~kg} / \mathrm{ha}$ has been shown to increase rice grain yields (Snyder et al., 1986). Si incorporated before seeding at $1000 \mathrm{~kg} / \mathrm{ha}$ showed that Si alone and with fungicide increased the yields by $28 \%$ to $51 \%$ over the control (Seebold, 1998). However, recently Si fertilisation using chemical silicate at a rate of $100 \mathrm{~kg} /$ ha to $250 \mathrm{~kg} / \mathrm{ha}$ offers promising results to improve rice yield (Babu Rao \& Sushmitha, 2017). Therefore, the Si recommendation for rice varies between this range or higher, up to $500 \mathrm{~kg} / \mathrm{ha}$ depending on its chemical and physical nature and soil factors (Cuong et al., 2017; Han et al., 2018; Jafari et al., 2013; Patil et al., 2017). Calcium silicate is one of the most regularly used Si fertiliser incorporated into the soil before planting.

The role of $\mathrm{Si}$ in improving resistance against various stresses has been discussed thoroughly (Ma, 2004). In the meantime, other researchers (Adrees et al., 2015; Sahebi et al., 2015) have illustrated several factors affecting Si uptake and deposition in plants. Mechanisms of Si on plant improvement are associated with the plant stress responses against various environmental conditions (Figure 2). Thus, when a plant detects some form of stress, Si can effectively activate natural defence mechanisms by triggering a wide range of plant responses involving molecular and cellular processes.

Si plays a role in controlling the nutrition of rice minerals that are essential for rice growth and development. Its benefits include 


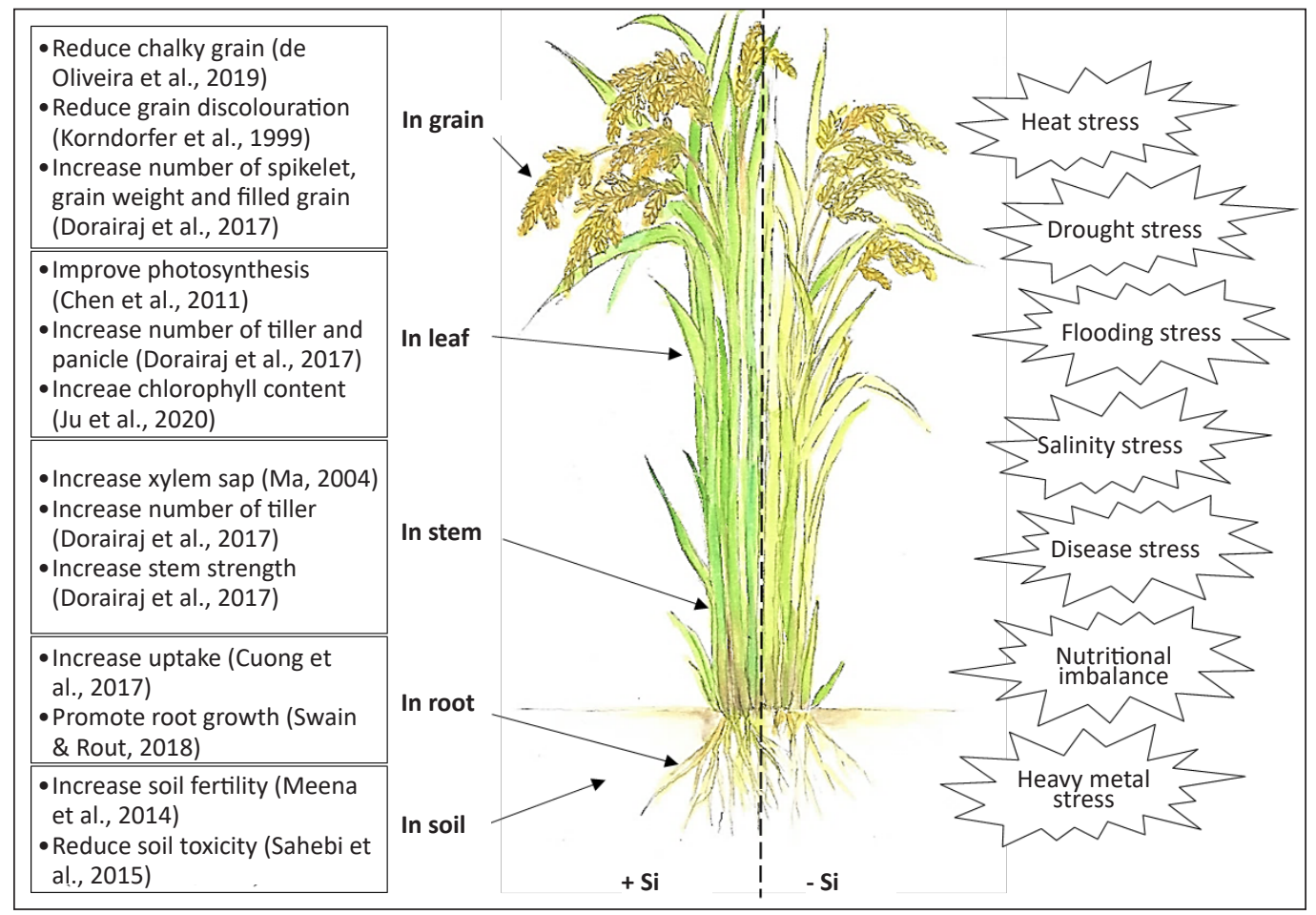

Figure 2. The hypothetical mechanism for Si-sufficiency and Si-deficiency in rice plant

improving fertiliser uptake efficiency, alleviating mineral toxicity (Sahebi et al., 2015), facilitating photosynthesis (Lavinsky et al., 2016), preventing lodging (Epstein, 1999), alleviating water (Agarie, 1998), enhancing the rice to be more resistant against diseases, and protecting rice against insect pests (Cooke \& Leishman, 2011; Liang et al., 2007). Si deficiency might expose the rice plants to all these issues, thus limiting the rice yield to increase further. Datnoff et al. (2001) reported that low Si in soils tends to lower other essential nutrients. This positive effect was attributed to the corrective action of $\mathrm{Si}$ amendments and the increased availability of $\mathrm{Si}, \mathrm{P}, \mathrm{Ca}$, and $\mathrm{Mg}$ to plants. In addition, $\mathrm{Si}$ can promote the oxidation power of root, and improve the soil condition, thus minimising the toxicity of heavy metals like Fe, Al, and Mn.

Additionally, Si can alleviate the imbalance in soil nutrients by increasing the $\mathrm{pH}$ and solubility of soil and increase the availability of phosphorus (P) and nitrogen (N) through the formation of silicified tissue in plants (Sahebi et al., 2015). The damaging effects of excess soil nutrients can also be alleviated by decreasing its extreme absorption. Si absorption in endodermal root cells can serve as an apoplastic barrier to reduce the uptake of soil nutrients by roots.

$\mathrm{Si}$ deposited in the plant cells forms a thick silicated layer on the leaf surface, thus alleviating water stress and reducing the loss of water transpiration. It also dramatically improves the light distribution within 
the canopy by keeping the leaves, stems, and culms of plants more erect (Epstein, 1999). Ma (2004) reported a decrease in self-shading and photosynthesis rate when leaves are more erect, particularly during grain filling related to starch accumulation in grain. Accumulation of Si increases the stem strength by increasing the thickness of the culm wall and the number of vascular bundles, thus resulting in a decrease in lodging. The deposition of $\mathrm{Si}$ in the leaf epidermal cells and cell walls of hulls creates a double layer of silica cuticle and silicacellulose on the surface of leaves, stems, and hulls. The impregnation of the cell wall with the Si particle improves the mechanical properties of plant tissues. It helps plants to bear various stress conditions. It decreases transpiration from panicle, thus reducing water loss so that the plant can withstand water deficiency and strong wind (Ma et al., 2001, 2002). Si is efficient in reducing the rate of transpiration from the hull by maintaining a high moisture condition within the hull.

In response to insect pests and pathogen attacks on the plants, various defence mechanisms activated or induced by $\mathrm{Si}$ application. Si has been shown to increase the resistance against diseases and pests by forming physical barriers on the tissue surface. The physical mechanism embeds Si deposition beneath the cuticle impeding pathogens entry and feeding activity of the insect pests. The biochemical defence may involve stimulation of defencerelated enzymes, which results in increased expression of defence genes, resulting in decreased tissue damage by herbivory and pathogen movement within plant tissues. Molecular defence modulates transcriptomic and proteomic regulations that improve plant resistance against insect pests and diseases (Islam et al., 2020). Si deposition enhances plant resistance against infection when $\mathrm{Si}$ is absorbed by the roots (Datnoff et al., 2007). Farnaz et al. (2012) have evaluated the effectiveness of Si between granular silica gel, which was applied directly to soil compared to liquid sodium silicate, which was applied as a foliar spray and tested on rice variety MR 219. They reported that supplying Si through the roots yielded higher Si content in the rice leaves than foliar application, consequently contributing to better protection against blast infection. NurulNahar et al. (2020) have reviewed options for controlling rice blast diseases. Instead of using a chemical fungicide as the last option, they suggested $\mathrm{Si}$ as one of the practical and sustainable methods. However, these approaches are still not commonly used in local rice cultivation.

Research has shown that $\mathrm{Si}$ also increases rice grain quality, resulting in higher grain-milling quality and greater whiteness per grain (Prabhu et al., 2012). It is known that milling quality can be affected when grains are chalky and immature since they are easy to crack during polishing resulting in decreased rice-milling recovery. According to Alvarez et al. (2004), Si application also offers a better grain appearance besides producing a healthier plant. Reasonable rates of Si can decrease the chalky grain and increase protein content 
and gel consistency (Zhang et al., 2007). In addition, $\mathrm{Si}$ is responsible for the formation of hulls, which can influence grain quality (Ansari et al., 2016). After leaves, large amounts of Si are deposited in the hulls as amorphous $\mathrm{SiO}_{2}$. Most of the beneficial effects on grain quality are attributed to Si deposition in the cell walls of hulls. According to Ma and Yamaji (2006), the content of Si rice was $8.05 \%$ in hulls, and $4.21 \%$ in leaves, while rice with low levels of Si only had $1.44 \%$ and $0.48 \%$ in the hull and leaves, respectively. Plants that can absorb and accumulate a large amount of $\mathrm{Si}$ are beneficial because this element can increase stress-resistant, particularly for Si-accumulator plants, thus enhancing grain quality. According to Mizuno (1987), the poor quality milky-white grains exhibited low Si content in the hulls, parallel with the Si content in the straw. The involvement of $\mathrm{Si}$ affected the cell wall formation in the spikelet before heading (Inanaga et al., 2002). Research by de Oliveira et al. (2019) has revealed that $\mathrm{Si}$ fertilisation, combined with fungicide application, can reduce the percentage of chalky kernels and vitreous grains of rice cultivars sensitive to rice blast.

In terms of nutritional quality, adding $\mathrm{Si}$ as fertiliser could increase the protein concentration and mineral elements $(\mathrm{Zn}, \mathrm{Ca}$, $\mathrm{Mg}$ ). Application of $\mathrm{Si}$ at rice booting stage could increase the concentration of most of the amino acids in brown and milled rice of Korean japonica rice (Q. Liu et al., 2017). X. Liu et al. (2020) also proved that Si, together with selenium (Se), could increase the protein content of hybrid rice in China, besides increasing the rice yield by $17.15 \%$ to $25.45 \%$. Research by Mo et al. (2017) showed that Si fertiliser had improved the yield and aromatic characteristics in high-quality aromatic rice in Hunan, China. The content of 2-acetyl-1-pyrroline (2-AP), the principal aromatic compound that contributes to the aroma character in fragrant rice, has also increased. These valuable discoveries serve as a guideline for applying Si fertiliser to produce highquality rice.

\section{CONCLUSION}

Silicon (Si) has been shown to significantly improve the soil structure, increase the efficiency of NPK fertilisers, alleviate the toxicity of metals, enhance the plant's resistance against diseases or pests and other environmental stresses. All of these factors can contribute to an increase in yield. Si has also been proven to improve the milling quality, grain quality both physically and chemically, and minimise chalkiness. Other than the strategy of developing new varieties with a reduced chalky grain percentage, the chalkiness problem can also be eliminated by adding Si as a nutrient to the plant. Therefore, adding Si as fertiliser during planting would be an effective way to improve the rice yield and grain quality, including minimising grain chalkiness. The reduction of chalky grains can also ensure the production of good quality rice grains. The proper of Si rate, time and application method should be studied and implemented for Malaysian rice varieties and then integrated into the rice cultivation systems. 


\section{ACKNOWLEDGEMENTS}

The authors gratefully acknowledge Universiti Putra Malaysia for providing study opportunities and financial support under the Putra Young Initiative Grant (GPIPM/2018/9593300). The authors would also like to thank scientist Mrs. Azimah Abd Kadir for her contribution to the figure drawing in this paper.

\section{REFERENCES}

Adrees, M., Ali, S., Rizwan, M., Zia-ur-Rehman, M., Ibrahim, M., Abbas, F., Farid, M., Qayyum, M. F., \& Irshad, M. K. (2015). Mechanisms of silicon-mediated alleviation of heavy metal toxicity in plants: A review. Ecotoxicology and Environmental Safety, 119, 186-197. https://doi. org/10.1016/j.ecoenv.2015.05.011

Agarie, S. (1998). Effects of silicon on tolerance to water deficit and heat stress in rice plants (Oryza sativa L.), monitored by electrolyte leakage. Plant Production Science, 1(2), 96-103. https:// doi.org/10.1626/pps.1.96

Agostinho, F. B., Tubana, B. S., Martins, M. S., \& Datnoff, L. E. (2017). Effect of different silicon sources on yield and silicon uptake of rice grown under varying phosphorus rates. Plants, 6(3), 35. https://doi.org/10.3390/plants6030035

Al-Amin, A. Q., Azam, M. N., Yeasmin, M., \& Fatimah, K. (2010). Policy challenges towards potential climate change impacts: In search of agro-climate stability. Scientific Research and Essays, 5(18), 2681-2685. https://doi. org/10.5897/SRE. 9000740

Alvarez, J., Datnoff, L. E., \& Snyder, G. H. (2004). The economics of silicon applications on rice and sugarcane in Florida. University of Florida's Institute of Food and Agricultural Sciences (UF/ IFAS).
Ansari, T. H., Iwasaki, K., Yoshida, T., \& Yamamoto, Y. (2016). Status of nutrient elements in rice grain in relation. Bangladesh Agronomy Journal, 19(2), 125-137. http://doi.org/10.3329/baj. v19i2.31861

Babu Rao, G., \& Sushmitha, P. (2017). Silicon uptake, transportation and accumulation in rice. Journal of Pharmacognosy and Phytochemistry, 6(6), 290-293.

Cao, X., Wen, H., Li, C., \& Gu, Z. (2009). Differences in functional properties and biochemical characteristics of congenetic rice proteins. Journal of Cereal Sciences, 50(2), 184-189. https://doi.org/10.1016/j.jcs.2009.04.009

Chen, W., Yao, X., Cai, K., \& Chen, J. (2011). Silicon alleviates drought stress of rice plants by improving plant water status, photosynthesis and mineral nutrient absorption. Biological Trace Element Research, 142(1), 67-76. https://doi. org/10.1007/s12011-010-8742-x

Cheng, F., Zhong, L., Zhao, N., Liu, Y., \& Zhang, G. (2005). Temperature induced changes in the starch components and biosynthetic enzymes of two rice varieties. Journal of Plant Growth Regulation, 46(1), 87-95. https://doi. org/10.1007/s10725-005-7361-6

Chun, A., Song, J. Kim, K. J., \& Lee, H. J. (2009). Quality of head and chalky rice and deterioration of eating quality by chalky rice. Journal of Crop Science and Biotechnology, 12(4), 239-244. https://doi.org/10.1007/s12892-009-0142-4

Cooke, J., \& Leishman, M. R. (2011). Is plant ecology more siliceous than we realize?. Trends in Plant Science, 16(2), 61-68. https://doi.org/10.1016/j. tplants.2010.10.003

Cooper, N. T. W., Siebenmorgen, T. J., \& Counce, P. A. (2008). Effects of nighttime temperature during kernel development on rice physicochemical properties. Cereal Chemistry, 85(3), 276-282. https://doi.org/10.1016/j.fcr.2011.03.012 
Cuong, T. X., Ullah, H., Datta, A., \& Hanh, T. C. (2017). Effects of silicon-based fertilizer on growth, yield and nutrient uptake of rice in tropical zone of Vietnam. Rice Science, 24(5), 283-290. https://doi.org/10.1016/j. rsci.2017.06.002

Datnoff, L. E., Rodrigues, F. A., \& Seebold, K. W. (2007). Silicon and plant nutrition. In L. E. Datnoff, W. H. Elmer, \& D. M. Huber (Eds.), Mineral nutrition and plant disease (pp. 233246). APS Press.

Datnoff, L. E., Seebold, K. W., \& Correa-V, F. J. (2001). Chapter 10 The use of silicon for integrated disease management: Reducing fungicide applications and enhancing host plant resistance. Studies in Plant Science, 8, 171-184. https://oi.org/10.1016/S0928-3420(01)80014-8

de Oliveira, L. M., Marchesan, E., de David, R., Werle, I. S., Aramburu, B. B., Donato, G., da Silva, A. L., \& da Costa, I. F. D. (2019). Occurrence of rice blast on and grain quality of irrigated rice fertilized with nitrogen and silicates. Pesquisa Agropecuária Brasileira, 54, e00295. https://doi. org/10.1590/S1678-3921.pab2019.v54.00295

Dorairaj, D., \& Ismail, M. R. (2017). Distribution of silicified microstructures, regulation of cinnamyl alcohol dehydrogenase and lodging resistance in silicon and paclobutrazol mediated Oryza sativa. Frontiers in Physiology, 8, 1-19. https:// doi.org/10.3389/fphys.2017.00491

Ebron, G. (2013). In search of the perfect grain. Rice Today, 12, 15-17.

Emam, M. M., Khattab, H. I., Helal, N. M., \& Deraz A. E. (2014). Effect of selenium and silicon on yield quality of rice plant grown under drought stress. Australian Journal of Crop Science, 8(4), 596-605.

Epstein, E. (1999). Silicon. Annual Review of Plant Physiology and Plant Molecular Biology, 50, 641-664. https://doi.org/10.1146/annurev. arplant.50.1.641
Farnaz, A. B., Kadir, J. Nasehi, A. Rahaghi, S. R. H., \& Sajili, H. (2012). Effect of silicon on rice blast disease. Pertanika Journal of Tropical Agricultural Science, 35(S), 1-12.

Fitzgerald, M. A., \& Resurreccion, A. P. (2009). Maintaining the yield of edible rice in warming world. Functional Plant Biology, 36(12), 10371045. https://doi.org/10.1071/FP09055

Gumel, D. Y., Abdullah, A. M., Mohd. Sood, A., Elhadi, R. E., Jamalani M. A., \& Ahmed Ben Youssef, K. A. (2017). Assessing paddy rice yield sensitivity to temperature and rainfall variability in Peninsular Malaysia using DSSAT model. International Journal of Applied Environmental Sciences, 12(8), 1521-1245.

Guntzer, F., Keller C., \& Meunier J. D. (2012). Benefits of plant silicon for crops: A review. Agronomy for Sustainable Development, 32(1), 201-213. https://doi.org/10.1007/s13593-0110039-8

Han, Y. Q, Wen, J. H, Peng, Z. P, Zhang, D. Y., \& Hou, M. L. (2018). Effects of silicon amendment on the occurrence of rice insect pests and diseases in a field test. Journal of Integrative Agriculture, 17(10), 2172-2181. https://doi.org/10.1016/ S2095-3119(18)62035-0

Haynes, R. J. (2014). A contemporary overview of silicon availability in agricultural soils. Journal Plant Nutrition and Soil Science, 177(6), 831844. https://doi.org/10.1002/jpln.201400202

Heckman, J. R. (2012). The soil profile. Rutgers Cooperative Extension, Plant Biology and Pathology Department, University of New Jersey.

Hodson, M. J., White, P. J., Mead, A., \& Broadley, M. R. (2005). Phylogenetic variation in the silicon composition of plants. Annals of Botany, 96(6), 1027-1046. https://doi.org/10.1093/aob/mci255

Inanaga, S., Higuchi, Y., \& Chishaki, N. (2002). Effect of silicon application on reproductive growth 
of rice plant. Soil Science and Plant Nutrition, 48(3), 341-345. https://doi.org/10.1080/003807 68.2002 .10409210

Ishimaru, T., Horigane, A. K., Ida, M., Iwasawa, N., San-oh, Y. A., Nakazono, M., Nishizawa, N. K., Masumura, T., Kondo, M., \& Yoshida, M. (2009). Formation of grain chalkiness and changes in water distribution in developing rice caryopses grown under high-temperature stress. Journal of Cereal Science, 50(2), 166-174. https://doi.org/10.1016/j.jcs.2009.04.011

Islam, W., Tayyab, M., Khalil, F., Hua, Z., Huang, Z., \& Chen, H. Y. (2020). Silicon-mediated plant defense against pathogens and insect pests. Pesticide Biochemistry and Physiology, 168, 104641. https://doi.org/10.1016/j. pestbp. 2020.104641

Jafari, H., Dastan, S., Nasiri, A. R., Valaei, L., \& Eslamii, H. R. (2013). Nitrogen and silicon application facts on rice growth parameters at Alborz Mountain Range. Electronic Journal of Biology, 9(4), 72-76.

Ju, S., Wang, L., \& Chen, J. (2020). Effects of silicon on the growth, photosynthesis and chloroplast ultrastructure of Oryza sativa L. seedlings under acid rain stress. Silicon, 12(3), 655-664. https:// doi.org/10.1007/s12633-019-00176-8

Kaneko, K., Sasaki, M., Kuribayashi, N., Suzuki, H., Sasuga, Y., Shiraya, T., Inomata, T., Itoh, K., Baslam, M., \& Mitsui, T. (2016). Proteomic and glycomic characterization of rice chalky grains produced under moderate and high-temperature conditions in field system. Rice, 9(1), 26. https:// doi.org/10.1186/s12284-016-0100-y

Kim, S. S., Lee, S. E. Kim, O. W., \& Kim, D. C. (2000). Physicochemical characteristics of chalky kernels and their effects on sensory quality of cooked rice. Cereal Chemistry, 77(3), 376-379. https://doi.org/10.1094/CCHEM.2000.77.3.376

Korndörfer, G. K, Datnoff L. E., \& Corrêa, G. F. (1999). Influence of silicon on grain discoloration and upland rice grown on four savanna soils of Brazil. Journal of Plant Nutrition, 22(1), 93-102. https://doi.org/10.1080/01904169909365609

Lavinsky, A. O., Detmann, K. C., Reis, J. V., Ávila, R. T., Sanglard, M. L., Pereira, L. F., Sanglard, L. M. V. P., Rodrigues, F. A., Araújo, W. L., \& DaMatta, F. M. (2016). Silicon improves rice grain yield and photosynthesis specifically when supplied during the reproductive growth stage. Journal of Plant Physiology, 206, 125-132. https://doi.org/10.1016/j.jplph.2016.09.010

Li, N., Feng, A., \& Liu, N. (2020). Silicon application improved the yield and nutritional quality while reduced cadmium concentration in rice. Environmental Science and Pollution Research, 27(11), 20370-20379. https://doi.org/10.1007/ s11356-020-08357-4

Liang, Y., Nikolic, M., Elanger, R. B., Gong, H., \& Song, A. (2015). Effect of silicon on crop growth, yield and quality. In Silicon in agriculture (pp. 209-223). Springer. https://doi.org/10.1007/97894-017-9978-2_11

Liang, Y., Sun, W., Zhu, Y. G., \& Christie, P. (2007). Mechanisms of silicon-mediated alleviation of abiotic stresses in higher plants: A review. Environmental Pollution, 147(2), 422-428. https://doi.org/10.1016/j.envpol.2006.06.008

Lisle, A. J., Martin, M., \& Fitzgerald, M. A. (2000). Chalky and translucent rice grains differ in starch composition and structure and cooking properties. Cereal Chemistry, 77(5), 627-632. https://doi.org/10.1094/CCHEM.2000.77.5.627

Liu, Q., Zhou, X., \& Sun, Z. (2017). Application of silicon fertilizer affects nutritional quality of rice. Chilean Journal of Agricultural Research, 77(2), 163-170. http://doi.org/10.4067/S071858392017000200163

Liu, X., Huang, Z., Li, Y., Xie, W., Li, W., Tang, X., Ashraf, U., Kong, L., Wu, L., Wang, S., \& Mo, Z. (2020). Selenium-silicon (Se-Si) induced modulations in physio-biochemical 
responses, grain yield, quality, aroma formation and lodging in fragrant rice. Ecotoxicology and Environmental Safety, 196, 110525. https://doi. org/10.1016/j.ecoenv.2020.110525

Ma, J. F. (2004). Role of silicon in enhancing the resistance of plants to biotic and abiotic stresses. Soil Science and Plant Nutrition, 50(1), 11-18. https://doi.org/10.1080/00380768.2004.1040 8447

Ma, J. F., \& Takahashi E. (2002). Soil, fertilizer, and plant silicon research in Japan. Elsevier.

Ma, J. F., \& Yamaji, N. (2006). Silicon uptake and accumulation in higher plants. Trends in Plant Science, 11(8), 392-397. https://doi. org/10.1016/j.tplants.2006.06.007

Ma, J. F., \& Yamaji, N. (2008). Functions and transport of silicon in plants. A review. Cellular and Molecular Life Sciences, 65(19), 3049-3057. https://doi.org/10.1007/s00018-008-7580-x

Ma, J. F., \& Yamaji, N. (2015). A cooperative system of silicon transport in plants. Trends in Plant Science, 20(7), 435-442. https://doi. org/10.1016/j.tplants.2015.04.007

Ma, J. F., Goto, S., Tamai, K., \& Ichii, M. (2001). Role of root hairs and lateral roots in silicon uptake by rice. Plant Physiology, 127(4), 1773-1780. https://doi.org/10.1104/pp.010271

Ma, J. F., Nishimura, K., \& Takahashi, E. (1989). Effect of silicon on the growth of rice plant at different growth stages. Soil Science and Plant Nutrition, 35(3), 347-356. https://doi.org/10.10 80/00380768.1989.10434768

Ma, J. F., Tamai, K., Ichii, M., \& Wu, G. F. (2002). A rice mutant defective in Si uptake. Plant Physiology, 130(4), 2111-2117. https://doi. org/10.1104/pp.010348

Ma, J. F., Yamaji, N., \& Mitani-Ueno, N. (2011). Transport of silicon from roots to panicles in plants. Proceedings of the Japan Academy Series
B: Physical and Biological Sciences, 87(7), 377385. https://doi.org/10.2183/pjab.87.377

Meena, V. D., Dotaniya, M. L., Coumar, V., Rajendiran, S., Ajay, Kundu, S., \& Subba Rao, A. (2014). A case for silicon fertilization to improve crop yields in tropical soils. Proceedings of the National Academy of Sciences India Section B Biological Sciences, 84(3), 505-518. https://doi. org/10.1007/s40011-013-0270-y

Ministry of Agriculture and Food Industries Malaysia. (2019). Agrofood Statistics 2019. https:// www.mafi.gov.my/documents/20182/273021/ Perangkaan+Agromakanan +2019. pdf/196be0d7-e223-46fb-88c3-6a592f52b9fe

Mizuno, N. (1987). Effects of silica on hull weight and ripening of rice plants. Journal of Plant Nutrition, 10(9-16), 2159. https://doi. org/10.1080/01904168709363767

Mo, Z., Lei, S., Ashraf, U., Khan, I., Li, Y., Pan, S., Duan, M., Tian, H., \& Tang, X. (2017). Silicon fertilization modulates 2-acetyl-1-pyrroline content, yield formation and grain quality of aromatic rice. Journal of Cereal Science, 75, 17-24. https://doi.org/10.1016/j.jcs.2017.03.014

Nhan, P. P., Dong, N. T., Nhan, H. T., \& Chi, N. T. M. (2012). Effect of OryMaxSL and SiliysolMS on growth and yield of MTL560 rice. World Applied Sciences Journal, 19(5), 704-709.

Ning, D., Liang, Y., Liu, Z., Xiao, J., \& Duan, A. (2016). Impacts of steel-slag-based silicate fertilizer on soil acidity and silicon availability and metals-immobilization in a paddy soil. PLOS One, 11(12), 1-15. https://doi.org/10.1371/ journal.pone. 0168163

NurulNahar, E., Adam, P., Mazidah, M., Roslan, I., \& Rafii, M. Y. (2020). Rice blast disease in Malaysia: Options for its control. Journal of Tropical Agriculture and Food Science, 48(1), 11-23. 
Okuda, A., \& Takahashi. E. (1961). Studies on the physiological role of $\mathrm{Si}$ in crop plants: 1 . Discussion on the Si deficient culture method. Journal of the Science of Soil and Manure, 32, 475-480.

Patil, A. A., Durgude, A. G., Pharande, A. L., Kadlag, A. D., \& Nimbalkar, C. A. (2017). Effect of calcium silicate as a silicon source on growth and yield of rice plants. International Journal of Chemical Studies, 5(6), 545-549.

Patindol, J., \& Wang, Y. J. (2003). Fine structures and physicochemical properties of starches from chalky and translucent rice kernels. Journal of Agricultural and Food Chemistry, 51, 27772784. https://doi.org 10.1021/jf026101t

Patindol, J., Siebenmorgen, T. J., \& Wang, Y. J. (2015). Impact of environmental factors on rice starch structure: A review. Starch, 67(1-2), 42-54. https://doi.org/10.1002/star.201400174

Prabhu, A. S., Barbosa Filho, M. P., Datnoff, L. E., Snyder, G. H., Berni, R. F., Rodrigues, F. A., \& Dallagnol, L. J. (2012). Silicon reduces brown spot severity and grain discoloration on several rice genotypes. Tropical Plant Pathology, 37(6), 409-414. https://doi.org/10.1590/S198256762012000600005

Radziah, M. L., Engku Elini, E. A., Tapsir, S., \& Mohamad Zabawi, A. G. (2010). Food security assessment under climate change scenario in Malaysia. Palawija News, 27(1), 1-5.

Rajamoorthy, Y., Abdul Rahim, K., \& Munusamy, S. (2015). Rice industry in Malaysia: Challenges, policies and implications. Procedia Economics and Finance, 31(15), 861-867. https://doi. org/10.1016/s2212-5671(15)01183-1

Sahebi, M., Hanafi, M. M., Siti Nor Akmar, A., Rafii, M. Y., Azizi, P., Tengoua, F. F., Nurul Mayzaitul Azwa, J., \& Shabanimofrad, M. (2015). Importance of silicon and mechanisms of biosilica formation in plants. BioMed Research
International, 2015, 396010. https://doi. org/10.1155/2015/396010

Savant, N. K., Snyder, G. H., \& Datnoff, L. E. (1997). Silicon management and sustainable rice production. Advances in agronomy, 58, 151-199. https://doi.org/10.1016/S0065-2113(08)60255-2

Seebold, K. W. (1998). The influence of silicon fertilization on the development and control of blast, caused by Magnaporthe grisea (Hebert) Barr, in upland rice [Doctoral's dissertation, University of Florida]. UF Institutional Repository. https://ufdc.ufl.edu/ AA00028902/00001

Siregar, A. F., Sipahutar, I. A., Anggria, L., \& Yufdi, M. P. (2021). Improving rice growth and yield with silicon addition in Oxisols. In IOP Conference Series: Earth and Environmental Science (Vol. 648, No. 1, p. 012202). IOP Publishing. https:// doi.org/10.1088/1755-1315/648/1/012202

Snyder, G. H., Jones, D. B., \& Gascho, G. J. (1986). Silicon fertilization of rice on Everglades Histosols. Soil Science Society of America Journal, 50(5), 1259-1263. https://doi.org/10.2136/ sssaj1986.03615995005000050035x

Swain, R., \& Rout, G. R. (2018). Effect of silicon interaction with nutrients of rice. Journal of Experimental Biology and Agriculture Sciences, 6(4), 717-731. http://doi. org/10.18006/2018.6(4).717.731

Takahashi, E. (1995). Uptake mode and physiological functions of silica. Science Rice Plant, 2, 58-71.

US Department of Agriculture. (2021). World production volume of milled rice from 2008/2009 to 2019/2020. https://www.statista.com/ statistics/271972/world-husked-rice-productionvolume-since-2008/

Vaghefi, N., Shamsudin, M. N., Radam, A., \& Rahim, K. A. (2013). Impact of climate change on rice yield in the main rice growing areas of Peninsular 
Malaysia. Research Journal of Environmental Sciences, 7(2), 59-67. https://doi.org/10.3923/ rjes.2013.59.67

Wei, C., Qin, F., Zhu, L., Zhou, W., Chen, Y., \& Wang, Y. (2010). Microstructure and ultrastructure of high-amylose rice resistant starch granules modified by antisense RNA inhibition of starch branching enzyme. Journal of Agricultural and Food Chemistry, 58, 1224-1232. https://doi. org/10.1021/jf9031316

Yamakawa, H., \& Hakata, M. (2010). Atlas of rice grain filling-related metabolism under high temperature: Joint analysis of metabolome and transcriptome demonstrated inhibition of starch accumulation and induction of amino acid accumulation. Plant and Cell Physiology, 51(9), 795-809. https://doi.org/10.1093/pcp/pcq034

Yamakawa, H., Hirose, T., Kuroda, M., \& Yamaguchi, T. (2007). Comprehensive expression profiling of rice grain ripening-related genes under high temperature using DNA microarray. Plant Physiology, 144(1), 258-277. https://oi. org/10.1104/pp.107.098665
Yu, T., Jiang, W., Ham, T., Chu, S., Lestari, P. Lee, J., Kim, M., Xu, F., Han, L., Dai, L., \& Koh, H. (2008). Comparison of grain quality traits between japonica rice cultivars from Korea and Yunnan Province of China. Journal of Crop Science and Biotechnology, 11(2), 135-140.

Zhang, G. L., Dai, Q. G., Wang, J. W., Zhang, H. C., Huo, Z. Y., \& Ling, L. (2007). Effects of silicon fertilizer rate on yield and quality of japonica rice Wuyujing 3. Chinese Journal of Rice Science, 21(3), 299-303. https://doi.org/10.3321/j. issn:1001-7216.2007.03.014

Zhao, X. \& Fitzgerald, M. (2013). Climate change: Implications for the yield of edible rice. PLOS One, 8(6), e66218. https://doi.org/10.1371/ journal.pone.0066218

Zhaomiao, L., Deyi, Z., Xincheng, Z., Zunxin, W., Jinchao, L., Zhenghui, L. Ganghua, L., Shaohua, W., \& Yanfeng, D. (2015). Chalky part differs in chemical composition from translucent part of japonica rice grains as revealed by a notchedbelly mutant with white-belly. Journal of the Science of Food and Agriculture, 96(11), 39373943. https://doi.org/10.1002/jsfa.7793 